\title{
The fiscal impact of immigration to welfare states of the Scandinavian type
}

\author{
Marianne Frank Hansen ${ }^{1}$. \\ Marie Louise Schultz-Nielsen ${ }^{2}$ - Torben Tranæs ${ }^{3}$
}

Received: 18 September 2015 / Accepted: 5 February 2017 / Published online: 3 March 2017

(C) The Author(s) 2017. This article is published with open access at Springerlink.com

\begin{abstract}
In this paper, we examine the potential of immigration to strengthen fiscal sustainability, which is under pressure by an ageing population in many European countries. We look at a particularly challenging case, namely that of Denmark, which has extensive tax-financed welfare programmes that provide a high social safety net. The analysis is based on a forecast of the entire Danish economy made using a dynamic computable general equilibrium model with overlapping generations. We present life cycle estimates of the potential fiscal impact of immigration considering the cost of immigration on the margin as well as on average. The main conclusion is that immigrants from Western countries have a positive fiscal impact, while immigrants from non-Western countries have a large negative one, which is also the case when considering only non-refugee immigrants. The negative effect is caused by both a weak labour market performance and early retirement in combination with the universal Danish welfare schemes.
\end{abstract}

Keywords Immigration - Sustainable fiscal policy . Welfare benefits

JEL Classification F22 E62 · J61

Responsible editor: Klaus F. Zimmermann

Marie Louise Schultz-Nielsen

mls@rff.dk

1 The Danish Rational Economic Agents Model—DREAM, Amaliegade 44, 1256 Copenhagen K, Denmark

2 The Rockwool Foundation Research Unit, Sølvgade 10, 1307 Copenhagen K, Denmark

3 SFI-The Danish National Centre for Social Research, Herluf Trolles Gade 11, 1052 Copenhagen K, Denmark 


\section{Introduction}

In the debate concerning the challenges presented to a society by an ageing population, immigration is often mentioned as one of the possible solutions to securing income for the public purse. But, is it in fact a solution? Is it sensible from an economic point of view to increase immigration - for the economy in general, and for the public finances in particular? Moreover, is the answer to this question the same irrespective of the type of immigration and the type of welfare society under consideration? These questions are discussed in this paper. The focus will be on the effect of immigration on public finances, because the effects on the economy as a whole are likely to be small for the average citizen, being mainly distributional in character (Borjas 1990). ${ }^{1}$ We examine specifically a particularly challenging case, namely that of Denmark - a society with extensive tax-financed welfare programmes that provide a high social safety net.

The high social safety net in Denmark makes it especially difficult for the country to make immigration a contributory factor to fiscal sustainability, in particular immigration from poor countries. On the one hand, the expensive income-tax-financed welfare programmes require a high average employment rate for the operation as such to be fiscally sustainable, and on the other hand, the high social safety net induces high effective minimum wages that make it difficult for newcomers to get into employment unless they are very productive to begin with, which many immigrants from poor countries tend not to be. Thus, for immigration to improve fiscal sustainability in a high-spending welfare country, the immigrants' skills need to be both high and compatible with the requirements of the labour market. To what extent this is the case is the topic of this paper.

Specifically, we ask to what extent the various population groups in Denmark contribute to public finances today, and how much we can expect the immigrant groups to contribute if we look forward in time. We are interested in the total net effectincluding indirect effects from demographic changes, from educational attainment, from the labour market, etc. - and for consistency, we therefore make a forecast for the entire Danish economy. We compute how the net contributions to the public purse from people of Danish origin and from immigrants and second-generation immigrants of both Western and non-Western origins - with and without the refugee group - are expected to change over time. ${ }^{2}$

In all the computations, public transfers related to individuals (unemployment benefits, child benefits, taxes, etc.) and all publicly provided services linked to individuals (education, visits to the doctor, etc.) are assigned to each population group according to actual use. With regard to the remaining public expenditures, i.e. the costs of fixed public goods (armed forces, construction of roads and bridges, central administration, etc.), computations are made both on average where these costs are allocated equally across all individuals, meaning that immigrants are assigned the average cost of fixed public goods, and on the margin where these costs are ignored, meaning that the cost of providing fixed public goods to immigrants is assumed to be zero. The marginal

\footnotetext{
${ }^{1}$ See also the recent summary of the literature on this issue by Peri (2014).

${ }^{2}$ The non-Western countries are mainly poor countries, being non-OECD countries or low-income OECD countries plus a few richer Asian countries, as detailed in Section 2.
} 
approach is only relevant when considering immigration flows that are small relative to the size of the population.

In the following, we focus on three computations. First, we compute the annual net contributions to the public sector from each population group in each year from 2014 and onwards ${ }^{3}$ with the costs of fixed public goods being allocated equally across all individuals.

Second, subject to the assumption of equally distributed fixed public goods, we compute the present values of lifetime net contributions for both the entire cohort born in 2013 and for each of the population groups studied. We control for both the number of years of residence in the country and for the particular period of life when individuals resided in the country. ${ }^{4}$ These computations are also conducted for non-Western immigrants disregarding the group of refugees. This is relevant, because granting asylum to refugees is motivated by a wish to help, and thus to be compared with foreign aid rather than being evaluated as an investment to the country.

The results up until this point, with the costs of fixed public goods allocated equally to both natives and immigrants, suggest that immigration from non-Western countries represents a net cost to the public purse, while immigration from Western countries (richer countries) generates a net contribution. However, very small changes in the population size do not change the cost of providing fixed public goods. So, these results are not directly applicable for policy changes that only marginally affect the size of the population. The net fiscal benefit of small (enough) changes in the immigration population for instance should rather be assessed by setting the cost of providing fixed public goods to the newcomers to zero. Immediately, we can conclude that the net benefit to the public purse of Western immigration is positive on the margin, because this was the case even when the immigrants were allocated their full share of the cost of fixed public goods. But what about the benefit to the public purse on the margin when considering immigration from non-Western countries? To answer this question, we conduct a third computation by changing the yearly inflow of immigrants while keeping the total costs of fixed public goods unchanged, and then examining how this would affect public finances, measured in terms of fiscal sustainability. The fiscal impact of immigration from non-Western countries is found to be negative even when the provision of fixed public goods is unaffected by their number.

The calculations were carried out using the Danish Rational Economic Agents Model (DREAM), a dynamic computable general equilibrium model with overlapping generations. One advantage of working within this model framework is that it ensures that indirect effects are also included in the calculations. For instance, the tax revenue from income - for example, profit income - earned by natives, because of immigration, is included in our computation, thanks to the general equilibrium properties. Furthermore, the model encompasses projections of population growth, educational attainment, demographic characteristics and country of origin two generations ahead. The model predicts the total budget of the public sector year by year, which we will

\footnotetext{
${ }^{3}$ The time horizon of the model is in principle infinite, which is modelled by assuming that the model enters a steady state in year 2122 (the model runs for 115 periods). To illustrate the direction in which the annual figures evolve in, we present the results for a year almost between now and then, namely 2050.

${ }^{4}$ Here we have taken both return and re-entry migration into account based on the historical pattern.
} 
summarise and present both as the sustainability indicator $(\mathrm{SI})^{5}$ measured in percentages of GDP and as the average annual budget surplus in Euro.

The forecast is based on the economic structures of $2008^{6}$ and assumes a continuation of these, except that we have taken into account future changes that will occur as a consequence of reforms approved by Parliament up until 2012. These years represented an all-time low for the immigrant-native employment gap in Denmark. Aiming to study the potential contribution of immigration, 2008 is an obvious year on which to base expectations in order to answer our key question, namely, to what extent might immigration contribute to fiscal sustainability in a generous welfare state, and does this contribution vary between different immigrant groups? For robustness, we also simulate a scenario where-like in the years following 2008 - immigrant unemployment is hit disproportionally hard by a permanent shock.

Historically, the mix of immigrants coming to Denmark has on average been weak with respect to labour market qualifications. This was particularly the case up until the late 1990s, and in consequence, immigration resulted in a huge deficit to the public purse around the year 2000. This deficit was solely attributable to immigrants from poor countries (nonWestern). At around the same time, Germany was managing to attract both better-educated and more experienced immigrants than Denmark (Tranæs and Zimmermann 2004). ${ }^{7}$

The main reason for the unfavourable mix of immigrants to Denmark in terms of their employability at the time mentioned was the fact that Denmark received relatively few migrants who came to the country for work and study purposes. Around the year 2000, only $25 \%$ of the residence permits issued to people from non-Western countries were for employment or education purposes, the remaining $75 \%$ being issued to refugees or family reunification immigrants.

The Danish immigration policy was not in general unusual at the time, apart from during the decade following the very liberal 1983 immigration act that was mainstreamed in the years after (see Bauer et al. 2004). Otherwise, it was based on a strict employment migration control enacted under the economic crises in the early 1970s like in many other European countries. Similarly, the within-EU migration, the asylum rules and family unification possibilities was also regulated by more or less the same rules under the EU and the UN, respectively.

However, the new immigration policy introduced around 2000 changed the picture described above dramatically, so that by 2008 the share of residence permits granted to non-Western immigrants for employment and education purposes had reached $80 \%$, and in addition, the total number of such permits granted had increased. ${ }^{8}$ This trend in residence

\footnotetext{
$\overline{5}$ This indicator corresponds to the indicator S2 used by the European Commission.

${ }^{6}$ The model is calibrated to the economic structures of 2008 adjusted for business cycle effects. Compliance with the structural features is only ensured at the macro level, leaving e.g. the distribution of labour market participation and unemployment across gender, age and origin unaltered throughout the forecast period.

${ }^{7}$ This is not due to a particular mix of nationalities among the immigrants to Denmark. Compared to the immigrants to Denmark, the immigrants to Germany were better educated and had longer work experience for each sending country.

${ }^{8}$ The new policy was based on (1) easy access for employment immigrants, (2) new restrictions on asylum procedures, (3) marriage reunification was restricted by age and time spent in the sending country versus in Denmark for the couple together (refugees were excepted from these restrictions) and (4) lower social assistance to non-working newcomers. Thus, the new policy aimed directly at changing the composition of residence permits in the direction of relatively fewer refugees and family unification permits and more work and education permits. See Tranæs (2012).
} 
permits seems to have been associated with an upward trend in employment rates among non-Western immigrants in Denmark that peaked in 2008 (Tranæs 2012). The gap between the employment rates of native Danes and non-Western immigrants dropped from 33 to 23 percentage points between 2000 and 2008, and consequently, the contribution from immigration to the public finances improved significantly over that period. Nevertheless, in 2008, the employment rate of non-Western immigrants was still only $56 \%$, compared to $79 \%$ for natives, and immigration from non-Western countries still created a deficit even under the assumption that the cost of providing fixed public goods to immigrants was zero, as shown by Gerdes et al. (2011). ${ }^{9}$ With the coming of the recession, the improvement in employment integration came to a halt, and in the years 2011 to 2013, it remained constant at a somewhat lower level than previously, with an employment rate gap between natives and non-Western immigrants of 26 percentage points. However, the most substantial economic recession in decades did not send the employment gap back to where it was even around 2000, which suggests that the policy change during the 2000 s has had some structural effects. All in all, 2008 is a good baseline for a projection if we want to study the potential effect of immigration based on historical experience, and the recession years should then be considered for robustness.

By considering both cases where immigrants are paying the average per capita cost of fixed public goods and that of zero under the assumption that the cost of providing these goods to immigrants is zero (the marginal approach), we are following Dustmann and Frattini (2013). Although we arrive at the same overall picture for Denmark as they do for the UK - that immigrants from richer countries reduce the fiscal burden on the natives of the country and that immigrants from poor countries perform worse in terms of their contribution than those from richer countries - we arrive at a less optimistic picture with regard to immigration from non-Western countries than Dustmann and Frattini do for non-EEA immigrants. They find that even the recently arrived non-EEA immigrants to the UK make a positive net contribution to the public purse; we consistently find sizeable negative net contributions in the case of non-Western immigration to Denmark. The employment rates of non-Western citizens in Denmark and non-EEA citizens in the UK are not that different, and although the employment rate of non-Western immigrants is slightly lower than that of the non-EEA immigrants, the similarity between the two levels suggests that the difference in the results is mainly linked to the general differences in the generosity of the two countries' welfare systems. This view is supported by the findings in Ruist (2014). Studying the fiscal implication of immigration from the new EU countries to Sweden, he finds zero or only small positive fiscal effects, suggesting that the effects of non-EU immigration to Sweden are negative, as the employment rate for these immigrants is much lower than that for EU immigrants. Altogether this suggests that the mix of immigrants is important when assessing their fiscal impact, and that for certain immigrant groups, welfare societies like those of Scandinavia face a considerable structural challenge with respect to achieving a net surplus for the public purse as a result of immigration from non-EU countries, something that has been confirmed later by Ruist (2015) and Flood and Ruist (2015).

\footnotetext{
${ }^{9}$ If refugees are excluded from the calculation, the overall contribution from all immigrants - from both poor and rich countries — was a small positive amount in 2008 .
} 
The methodological approach applied in the present study is related to that used by Schou (2006), who also used DREAM to assess the consequences of increasing the future yearly inflow of immigration by 5400 persons. He found that this increase would worsen the Danish fiscal sustainability problem by $0.14 \%$ of GDP or by $0.49 \%$ if all the immigrants were from non-Western countries and were considered to be paying the average per capita cost of fixed public goods. Schou does not compute the marginal costs of immigration, and immigrant employment was significantly lower in his base year of 2004 than in 2008; both factors tend to increase the financial burden. Other analyses calculating the net transfers based on cross-sectional data for first- and secondgeneration immigrants of Western and non-Western origin confirm this picture; see Wadensjö (2000, 2007) and Gerdes et al. (2011). Wadensjö and Gerdes (2004) also show that the net transfers per person are larger for non-Western immigrants in Denmark than in Germany; as in a similar case of the UK (Dustmann and Frattini 2013), this may be explained by differences in the mix of immigrant populations and the welfare systems of the countries, as discussed in Hinte and Zimmermann (2014).

This study goes further than previous studies of the fiscal effects of immigration by (1) considering life cycle estimates of the fiscal impact of different immigration groups by forecasting from the year with the smallest native-immigrant employment gap in recent history, (2) considering the fiscal effect of marginal changes in immigration (the marginal cost of immigration) as well as the fiscal effect of the immigration as such (the average cost), (3) computing the present values of lifetime net contributions for each population group controlling for both the number of years of residence in the country and for the particular periods of life the individuals resided in the country based on historically observed behaviour including migration patterns and (4) by assessing how much of the net cost of non-Western immigration is explained by the fact that many of these immigrants are refugees rather than ordinary immigrants and, thus, not admitted to the country based on an investment motive but on a desire to help.

This paper is organised as follows. Section 2 presents the data and the model. In Section 3, we present the baseline total net contributions year by year for the different population groups. Section 4 contains the life cycle computations, while Section 5 discusses fiscal sustainability under different possible immigration policies. Finally, Section 6 concludes and addresses the overriding question of the extent to which immigration from various parts of the world can contribute to solving the financing challenges faced by countries such as Denmark as a result of an ageing population.

\section{Data and methods}

The following provides a brief introduction to DREAM and to the assumptions on which the calculations are based.

\subsection{General description of the model}

Our results are based on the DREAM projections of 2013 (DREAM 2013b). The model estimates long-term economic activities and sustainability of economic policy on the basis of projections of the demographic composition, level of education and labour market participation of the Danish population. In particular, the model is frequently 
used to address the question of whether the present fiscal policy or specific changes to it are sustainable. The DREAM modelling system consists of a number of nested submodels which generate input to a computable general equilibrium (CGE) model with an infinite time horizon.

The first sub-model consists of a population projection and is based on assumptions concerning fertility rates, mortality rates and inward and outward migration including return and re-entry migration (DREAM 2013a). This projection is made in collaboration with Statistics Denmark and constitutes the official national population projection for Denmark. ${ }^{10}$

The next sub-model is concerned with determining the future education behaviour of the population. Using gender-, age- and origin-specific probabilities concerning the commencement, continuation, drop-out rate and completion of study programmes, the distribution of the future population on various education levels is calculated. Then, using gender-, age-, origin- and education-specific participation rates, the third submodel assigns the future population to numerous socioeconomic categories within and outside the labour force. Hence, the output from the third sub-model establishes the future proportions of the population within and outside the labour force, which serves as the primary input in the CGE model. Specifically, the characteristics in terms of education, employment, earnings, number of children, etc. of the immigrants evolve from information on gender, age and country of origin according to past experience.

On the basis of the information from the system of sub-models, the model can be used to forecast several components of the Danish economy. The model consists, first, of households that supply labour, demand goods and services, accumulate wealth (savings and pensions) and pay taxes to the public sector. The private sectors demand labour, produce goods, invest in capital, issue stocks, pay taxes and wages and receive subsidies. Finally, the public sector employs labour, requires financing from taxation, provides public services, pays transfers to households and pays interest on public debts. By taking into account expected future public revenues and spending, the model can be used to assess whether or not a given fiscal policy is sustainable.

In the DREAM projections of 2013, the size of the shortfall in the sustainability of fiscal policy measured by the sustainability index, SI, is calculated at $-0.04 \%$ of GDP, equivalent to an annual EUR -0.09 billion budget deficit, over the infinite time horizon. ${ }^{11}$ This means that the public sector will have a (small) financing need of EUR 0.09 billion every year in the future-which in turn means that future revenue will be virtually sufficient to cover future costs. After having been in surplus at the onset of the financial crises, the public budget went into deficit during the recession years. It is forecast to remain in deficit for many decades to come, as can be seen from Table 1, which shows key indicators of the macro-performance of the economy. ${ }^{12}$ This

\footnotetext{
${ }^{10}$ The projection is based on the previous observed migration pattern as well as on national and international forecast of future migration flows. In Denmark like in other countries, a part of the emigration is registered with a significant delay (up to 3 years after the emigration year, beyond which there are few new registrations). The population and the population forecasts are adjusted for this phenomenon, but it still introduced some extra uncertainty. This uncertainty has, however, limited consequences for the public finances, because employment and unemployment are based on registered salaries and benefits actually paid out, and the same with the tax revenue.

${ }^{11}$ As mentioned above, this indicator corresponds to indicator S2 used by the European Commission.

${ }^{12}$ In a growing economy, this does not contradict a sustainability index close to zero ( $-0.04 \%$ of GDP).
} 
calculation is based on the assumption that the current economic policy regime is continued and that the economic reforms of recent years (up until 2011) are implemented as planned having the expected effects. ${ }^{13}$

Participation rates are exogenous in DREAM, whereas unemployment is endogenously responding to the replacement rate between the benefit level and wages. The model is fitted to reproduce key macro-economic figures until 2020 from the most recent official forecast by the Ministry of Finance. The projection embodying all of the above is referred to as the baseline scenario.

The exercise we conduct is the following. Supposing that the economy evolves as officially expected, what then will be the net contributions to public finances of the different population groups considered?

\section{Distribution of net contributions according to origins of the contributors}

In order to divide up net contributions to public funds according to the origin of the contributors, all income to the Danish public sector should in principle be categorised according to the contributors' gender, age and origin. The definition of origin used here is in accordance with that used by Statistics Denmark (Danmarks Statistik 2013), which in outline is as follows:

Immigrants were born outside Denmark. Neither of their parents was a Danish national born in Denmark. Second-generation immigrants ${ }^{14}$ are born in Denmark. Neither of their parents is a Danish national born in Denmark. All individuals, regardless of their place of birth, who have at least one parent who is a Danish national born in Denmark, are defined as natives.

In the following, we distinguish between Western and non-Western countries in accordance with the official definition by Statistics Denmark. Western countries comprise the 28 countries of the European Union plus Andorra, Iceland, Lichtenstein, Monaco, Norway, San Marino, Switzerland, the Vatican State, Canada, the USA, Australia and New Zealand. All other countries are categorised as non-Western countries. Thus, the rich Asian countries are also in the non-Western group, and therefore, on average, it is a slightly richer group than what is usually called developing countries. However, they only compose $0.6 \%$ of the immigrant population in Denmark (both first and second generation). ${ }^{15}$

Calculations made using DREAM are carried out as follows. First, the calculation of the overall economic projection is performed, and then the public sector budget is broken down according to the gender, age and origin of individuals. In practice, dividing up public income and expenditure requires the use of a set of distribution keys as described in the Appendix.

\footnotetext{
${ }^{13}$ For a more detailed description of this economic forecast, see DREAM (2013b).

${ }^{14}$ In principle, all descendants of immigrants are included in this group if neither of their parents is a Danish national born in Denmark. In practice, this group currently consists almost entirely of second-generation immigrants and includes only a few third-generation immigrants.

15 These counties are Japan, Hong Kong, Singapore, South Korea and Taiwan. In any case, it would not change our conclusion if we were to move all the rich Asian countries from the non-Western to the Western group. The already big difference in the performance between the two country groups would just be slightly larger.
} 
Table 1 Macro-economic development, baseline projection

\begin{tabular}{lccc}
\hline & 2008 & 2015 & 2050 \\
& Level, EUR billions & $\begin{array}{l}\text { Index (fixed prices); } \\
2008=100\end{array}$ & 193 \\
\hline GDP & & 103 & 195 \\
Private consumption & EUR 230 billion & 105 & 202 \\
Public consumption & 110 & 104 & 52 \\
Net exports & 62 & 117 & 208 \\
Investments & 11 & 95 & 115 \\
Employment, no. & 47 & 102 & 3.1 \\
Unemployment, \% & $2,581,000$ & 4.0 & 69 \\
Retirement, age where public pension starts & 3.8 & 65 & -2.3 \\
Budget surplus, public sector, as \% of GDP & 65 & -2.9 & -24.5 \\
Net foreign debt, as \% of GDP & 2.3 & 2.6 & 2.3 \\
\hline
\end{tabular}

Source: DREAM (2013b)

\subsection{The composition of net contributions for each population group, 2014}

The result of dividing up net contributions according to origin is shown below for selected years, 2014 and 2050. The calculations are based on the long-term projections by DREAM (2013b), which tracks the Ministry of Finance's projected primary budget balance until the year of 2020. In order to avoid assigning too much weight to major fluctuations in the primary balance in certain years (for example, because of changes in the regulations on lump sum pension payments), it was decided to calculate an average net contribution of the years 2013-2015, and this average is being referred to hereafter as 2014 .

Table 2 shows how the expected annual public revenues and expenditures for 2014 are distributed by country of origin when the principles described above are applied. The calculations are shown in 2013 values (Euro/DKK=1/7.47). Such a table is computed for each year from 2013 and to infinity (in principle), which is managed by assuming that the model enters a steady state in year 2122. The annual figures constitute the base for both the life cycle computations and the long run fiscal sustainability measures.

Before looking at average life cycle contributions and fiscal sustainability, we will take a look at a short-term year, 2014, and a somewhat arbitrary year half a generation from now, 2050. There is no typical year in terms of demographic composition. The computations for the 2 years illustrate that some of the generational changes net out within immigration groups and that more pivotal is the composition of the immigration by country of origin. In Section 4, we will be considering the long run that fully incorporates the life cycle aspects.

As Table 2 shows, public revenue from taxes and VAT amounts to EUR 122 billion for 2014. The single largest item of income to the public purse is taxes deducted at income source (EUR 43 billion), deriving mostly from the taxation of wages, income transfers and pension payments. However, other direct taxes (EUR 24 billion) and other 
Table 2 Predicted annual public revenue and expenditure, distributed according to origin, 2014. EUR billions (2013 values)

\begin{tabular}{|c|c|c|c|c|c|c|}
\hline & Natives & $\begin{array}{l}\text { Western } \\
\text { immigrants }\end{array}$ & $\begin{array}{l}\text { Western } \\
\text { second- } \\
\text { generation } \\
\text { immigrants }\end{array}$ & $\begin{array}{l}\text { Non-Western } \\
\text { immigrants }\end{array}$ & $\begin{array}{l}\text { Non- } \\
\text { Western } \\
\text { second- } \\
\text { generation } \\
\text { immigrants }\end{array}$ & Total \\
\hline & $\%$ & $\%$ & $\%$ & $\%$ & $\%$ & $\begin{array}{r}\text { EUR } \\
\text { bn }\end{array}$ \\
\hline $\begin{array}{l}\text { Income from taxes } \\
\text { and VAT }\end{array}$ & 90.9 & 3.7 & 0.2 & 4.5 & 0.8 & 121.67 \\
\hline \multicolumn{7}{|l|}{ Expenditure on } \\
\hline Income replacement & 90.2 & 2.6 & 0.2 & 5.6 & 1.1 & -39.42 \\
\hline $\begin{array}{l}\text { Public individual } \\
\text { consumption }\end{array}$ & 90.3 & 2.5 & 0.4 & 3.7 & 3.0 & -47.83 \\
\hline Fixed public goods & 88.8 & 3.6 & 0.4 & 4.9 & 2.3 & -18.99 \\
\hline Other expenditures & 88.7 & 4.0 & 0.3 & 5.5 & 1.4 & -19.82 \\
\hline $\begin{array}{l}\text { Total net contributions, } \\
\text { EUR billion }\end{array}$ & -2.65 & 0.7 & -0.19 & -0.55 & -1.68 & -4.4 \\
\hline $\begin{array}{l}\text { Proportion of the } \\
\text { population }(\%)\end{array}$ & 89.0 & 3.5 & 0.4 & 4.9 & 2.3 & 100 \\
\hline
\end{tabular}

Source: DREAM projection of 2013 and own calculations

indirect taxes (EUR 28 billion) are also very significant. Other types of income contribute EUR 13 billion, while VAT from households makes up EUR 13 billion. On the outgoing side of the balance sheet, EUR 48 billion is spent on individual services, mainly in the areas of health, welfare and education, with sums of EUR 19 billion, EUR 14 billion and EUR 13 billion, respectively, for 2014. Expenditures on income replacement amount to EUR 39 billion, with old-age pensions (EUR 14 billion) as a major item. Fixed public spending (EUR 19 billion) is also a large item.

Since natives make up $89 \%$ of the population of Denmark, by far the greatest proportion of state income and expenditure is linked to this group. However, the contributions made by natives in the form of taxes and duties are a little smaller than the public expenditures targeted at this specific group. Hence, for 2014, the total net contribution from all natives is negative, EUR -2.7 billion. First-generation Western immigrants, in contrast, make a positive net contribution of EUR 0.7 billion, while second-generation Western immigrants make a negative net contribution of EUR -0.2 billion. In total, non-natives of Western origin living in Denmark make a positive net contribution to public funds of EUR 0.5 billion.

The fact that the net contribution is greater for first-generation immigrants than for the second generation is due in particular to the second generation being young and, therefore, not yet contributing significantly via tax payments. Seven out of ten secondgeneration Western immigrants are under 30 years of age (Danmarks Statistik 2013), whereas this is only the case for approximately one in three first-generation Western immigrants and natives. 
The net contribution is negative for people of non-Western origin as a whole, totalling EUR -2.2 billion, which is approximately $1 \%$ of GDP. For the first generation, the net contribution in 2014 is EUR -0.55 billion, while for second-generation immigrants, it is EUR -1.7 billion. Here again, the second-generation immigrants are much younger than the first generation, with nine out of ten second-generation nonWestern immigrants being under the age of 30. Consequently, revenue from taxes is low for this group, while in particular, expenditures related to education and care are high.

The fact that net contributions from non-Western immigrants are lower than those from Western immigrants is due to a lower rate of employment among non-Westerners, rather than any difference in age structure between the two immigrant groups. This leads to lower revenue from taxes and higher expenditure on social income transfers.

\subsection{The expected net contributions half a generation ahead}

To get an idea about where the projection is heading, we briefly present some level figures for 2050, a little less than half way towards the steady-state year of the model. The natives will make up $84 \%$ of the total population in 2050 down from $89 \%$, while non-Western immigrants and second-generation immigrants will make up 6.1 and $4.3 \%$ of the population, respectively, up from 4.9 and $2.3 \%$. Western first- and secondgeneration immigrants will comprise 4.5 and $1.6 \%$, up from 3.5 and $0.4 \%$. The distribution of public expenditures and incomes among population groups can be found in Table 3.

The total net contribution to public finances by natives in 2050 is expected to be EUR -1.8 billion. For first-generation Western immigrants, it is estimated that it will be EUR 1.5 billion, with the contribution from second-generation Western immigrants being EUR - 0.24 billion-overall, an expected surplus of EUR 1.2 billion from immigrants of Western origin.

The net contribution in 2050 is expected to be negative for people of non-Western origin, totalling EUR -0.8 billion. In contrast to the situation in 2014 , the first generation of immigrants will make a large negative net contribution (EUR -1.6 billion), while the second generation will contribute a positive sum (EUR 0.8 billion). This development will be largely attributable to changes in the age composition of the groups. Simplifying a little, we can say that the second-generation non-Western immigrants who were children in 2014 will have grown up by 2050 and become part of the workforce, while their parents will have aged and retired from work. At the same time, it is assumed that new non-Western immigrants will have settled in Denmark, and new second-generation immigrants will have been born-factors which will obviously affect the situation. Overall, however, it is expected that only four out of ten secondgeneration non-Western immigrants will be aged under 30 in 2050, and that, of course, makes a very substantial difference - compared to 2014-when calculating the net contribution from this group.

The Danish universal old-age pension system together with the social safety net implies that changes in the rate of employment and in the age composition are the main reasons that the net negative contributions to the public purse from the non-Western group will become less in magnitude over the period, but will nevertheless remain substantial in 2050. Table 4 shows that the employment rate for the non-Western group 
Table 3 Projected public revenues and expenditures, distributed by origin of individuals, 2050. EUR billions (2013 values)

\begin{tabular}{ccccccc}
\hline & Natives & $\begin{array}{l}\text { Western } \\
\text { immigrants }\end{array}$ & $\begin{array}{l}\text { Western } \\
\text { second- } \\
\text { generation } \\
\text { immigrants }\end{array}$ & $\begin{array}{l}\text { Non-Western } \\
\text { immigrants }\end{array}$ & $\begin{array}{l}\text { Non-Western } \\
\text { second-generation } \\
\text { immigrants }\end{array}$ & Total \\
\hline & $\%$ & $\%$ & $\%$ & $\%$ & $\%$ & EUR \\
bn
\end{tabular}

Source: Special run of DREAM and own calculations

of working age is projected to increase from $50.3 \%$ in 2014 to $60.1 \%$ in 2050, while the employment rate of the entire non-Western population above 16 years of age will increase only from $47.6 \%$ in 2014 to $50.4 \%$ in 2050 . Thus, the large increase in employment among working-age non-Western immigrants will be almost completely offset by there being more retired non-Western immigrants - and both pensioners and the unemployed receive social benefits. These calculations illustrate how important the age composition of the population is for net public contributions.

The general increase in the employment rates is due to the assumed decrease in unemployment from 4 to $3 \%$ and to an increase in the retirement age from 65 today to 69 in year 2050.

In order to see whether the negative net contributions are due purely to inauspicious demographic developments or whether weak labour market performance is also a major contributing factor, we consider the net contribution over time of the average member of the population in the next section.

\section{Present value of the net lifetime contributions of the 2013 cohort}

This section calculates the net contributions to public finances made over the course of a lifetime. In other words, we calculate how much an individual from a specific population group can be expected to contribute to public funds on average in each year of that person's life spent in Denmark. By studying the fiscal impact in this way, we control for the different sizes of the population groups, and for the fact that the net annual contribution varies over the course of a lifetime. 
Table 4 Employment rates by origin in the basic scenario, 2014 and 2050

\begin{tabular}{|c|c|c|c|c|c|c|c|}
\hline & Natives & $\begin{array}{l}\text { Western } \\
\text { immigrants }\end{array}$ & $\begin{array}{l}\text { Western } \\
\text { second- } \\
\text { generation } \\
\text { immigrants }\end{array}$ & $\begin{array}{l}\text { All } \\
\text { Western }\end{array}$ & $\begin{array}{l}\text { Non- } \\
\text { Western } \\
\text { immigrants }\end{array}$ & $\begin{array}{l}\text { Non-Western } \\
\text { second- } \\
\text { generation } \\
\text { immigrants }\end{array}$ & $\begin{array}{l}\text { All non- } \\
\text { Western }\end{array}$ \\
\hline \multicolumn{8}{|c|}{ Age $17+$} \\
\hline 2014 & 58.4 & 53.5 & 60.4 & 53.9 & 45.6 & 58.2 & 47.6 \\
\hline 2050 & 60.5 & 57.7 & 67.6 & 59.6 & 38.2 & 72.5 & 50.4 \\
\hline \multicolumn{8}{|c|}{ Aged 17-64 } \\
\hline 2014 & 74.1 & 60.6 & 66.7 & 61.0 & 48.7 & 58.3 & 50.3 \\
\hline 2050 & 78.3 & 65.7 & 69.5 & 66.6 & 50.0 & 73.3 & 60.1 \\
\hline
\end{tabular}

Source: DREAM projection of 2013

The calculation is based on people born in 2013, henceforth referred to as 'the 2013 cohort'. Tracking a cohort and calculating its average net contributions over the course of a lifetime has the advantage that the calculation does not depend on the age composition and size of the population at a given point in time. This facilitates comparison across population groups.

Below, we first construct the 2013 cohort. Then, we assign age-dependent public revenues and expenditures to each population group, and finally, by taking into account the number of years of residence in Denmark, the average present-value net contribution can be computed for each population group. The contribution is measured in Euro per person-year; one person living in Denmark for 10 years thus counts as 10 person-years.

\subsection{The 2013 cohort}

Figure 1 depicts a projection of the population belonging to the 2013 cohort. The bold line shows the total number of people in the cohort. The black line indicates the number of natives, while the grey and dotted lines show the numbers of first-generation and second-generation immigrants from non-Western countries, respectively. Western immigrants and second-generation immigrants are included in the total number but are not shown separately in the figure.

At age zero, the cohort consists of approximately 60,000 people, of whom the majority $(53,000)$ are natives. The cohort includes nearly 6000 second-generation immigrants, primarily of non-Western origin. The total number of cohort members will rise between the ages of 20 and 30, reaching a high point of almost 70,000. This is due to net immigration of those who were born abroad in the year of 2013. Of the 10,000 immigrants, around half will stem from non-Western countries; however, the proportion of non-Western immigrants will increase to around $65 \%$ as the cohort ages, because it is expected that a large proportion of the Western immigrants will leave the country again.

\subsection{Total contributions to public finances by population groups}

In order to calculate the net contribution of a specific population group, public sector revenues and expenditures are distributed between the various population groups as 


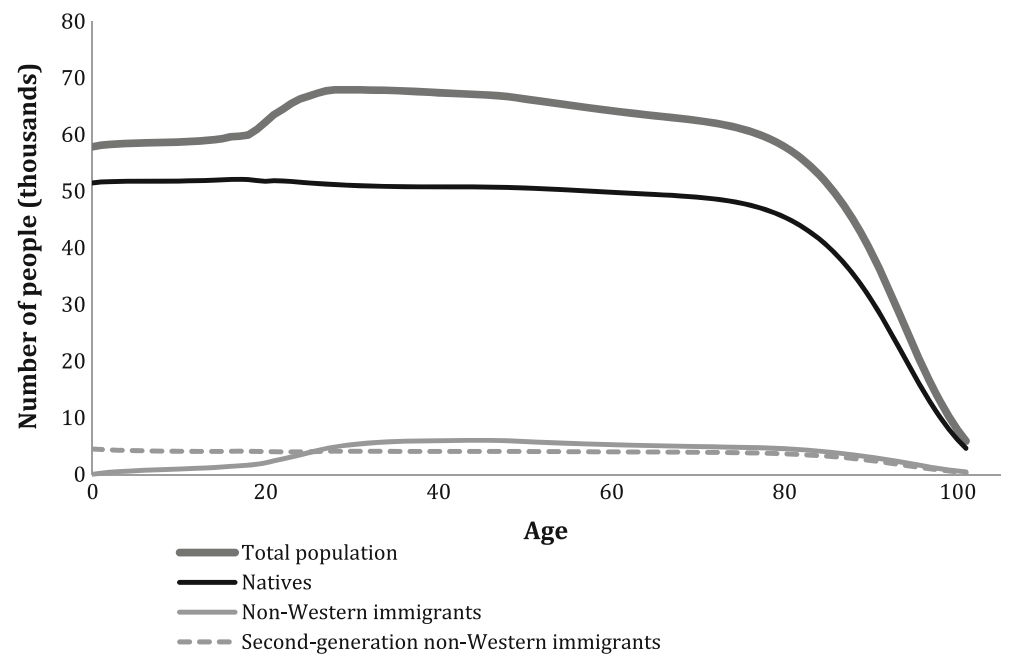

Fig. 1 Numbers of people in the 2013 cohort. Source: DREAM projection of 2013

discussed previously. In general terms, the income from taxable individuals comes from the adult population, while expenditures are spread across all age groups.

Figure 2 provides a more detailed picture of how the expenditures are distributed. Total projected expenditures over a lifetime for the 2013 cohort are broken down into expenditure types. The figure shows that for pre-school-age children, expenditures related to individual care make up the largest proportion of public spending. These expenditures primarily concern day care. From school age onwards - not surprisingly - costs regarding education dominate, right through until the age of 20, after which educational costs gradually decline. After this, the cost of transfer incomes gradually becomes more significant, and at the same time, individual health expenses begin to rise, though from a fairly low level. The cost of transfer incomes becomes the dominant

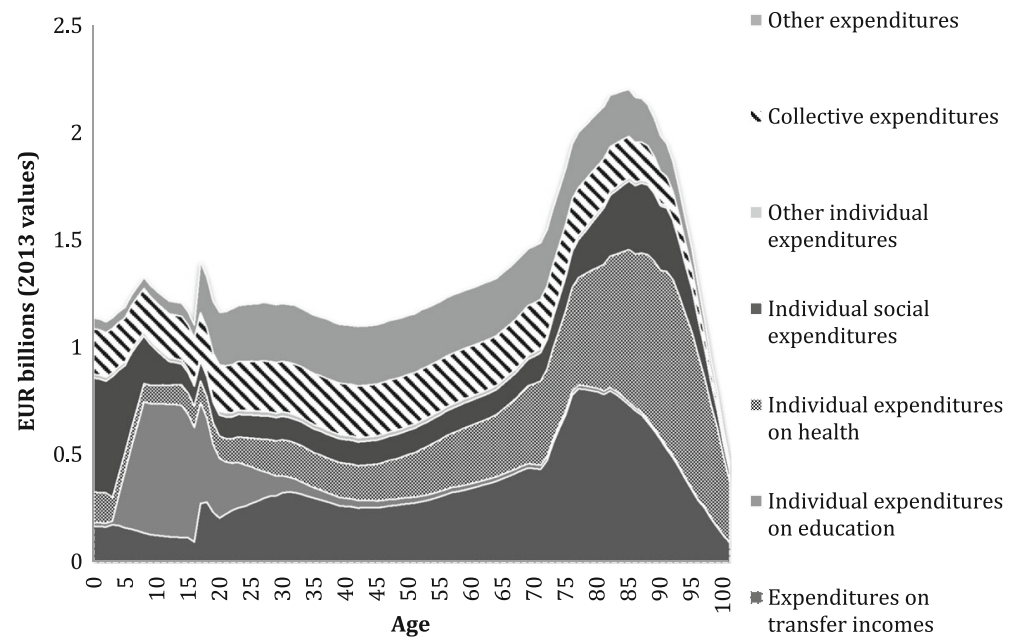

Fig. 2 Distribution of public expenditures over the course of a lifetime for the 2013 cohort. Source: DREAM projection of 2013 


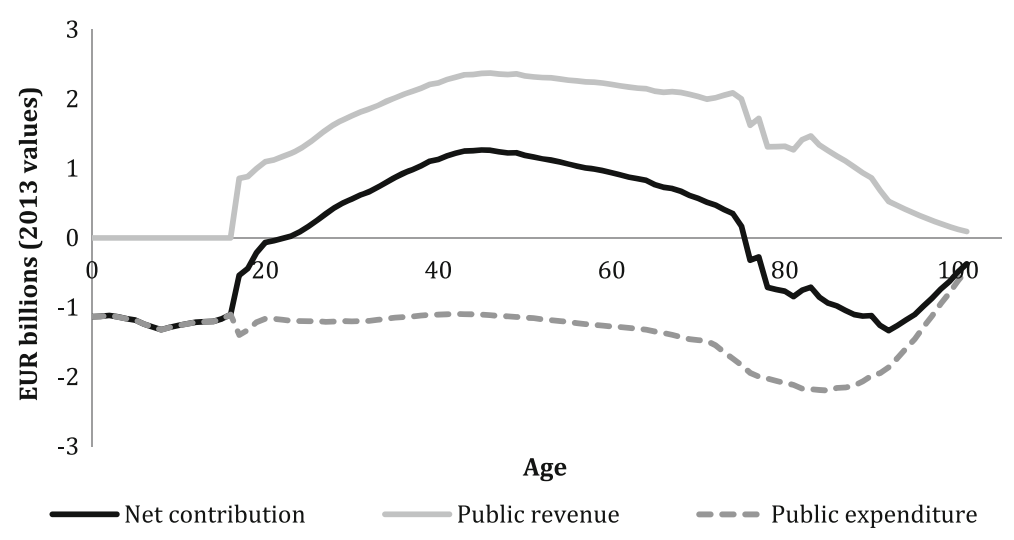

Fig. 3 Net contributions of the 2013 cohort. Source: DREAM projection of 2013

expenditure item right through until the age of around 80, after which health expenditure gradually takes over as the major cost as the cohort becomes older and more in need of care. Total costs will peak around the age of 85, after which they decrease as the cohort dies out.

Total net contributions of the entire 2013 cohort are shown in Fig. 3. The net contributions are divided into public revenues and expenditure over the lifetime of an individual. The dotted line in Fig. 3 shows total expenses over a lifetime and, thus, corresponds to the sum of expenses at each age shown in Fig. 2. Over the course of a lifetime, total expenses of the 2013 cohort will remain at a relatively constant level of around EUR 1.3 billion per year (in 2013 values) until around age 50, where after the expenditures will begin to rise, as stated above, peaking at around age 85 .

The grey line in Fig. 3 shows total public revenue, deriving in particular from taxes deducted at source (taxes on wages, transfer incomes and pensions) and from indirect taxes. Individuals under the age of 17 are assumed not to receive taxable income, hence not contributing to the public sector revenue. From the age of 17 and onwards, personal income is generated, and thus, transfers from households to the public sector will occur. Tax revenues from the 2013 cohort will rise rapidly over the period up until around age 45, when employment and consequently incomes will peak. After this, public revenue declines gradually as retirement age approaches. The increase in public revenue predicted at around age 80 is due to taxes on old-age pension payments.

The black line shows the overall net contribution and, thus, represents the difference between public sector revenue and expenditure. Since there is no public revenue before the age of 17, net contributions track public expenditure up until this point. From then onwards, tax revenue, and thus net contributions, rise - and from age 20 onwards, the net contribution will be positive. The increasing revenues and subsequently increasing net contributions will peak at around age 45 and thereafter will begin to fall, as a consequence of declining tax revenues and because expenditures increase as individuals grow older. The net contribution will become negative once more at around the age of 75 .

As described in Section 2, revenues and expenditures can be assigned to the various population groups. The result of this procedure is shown in Fig. 4, which depicts the net contributions of natives, non-Western immigrants and second-generation immigrants. 


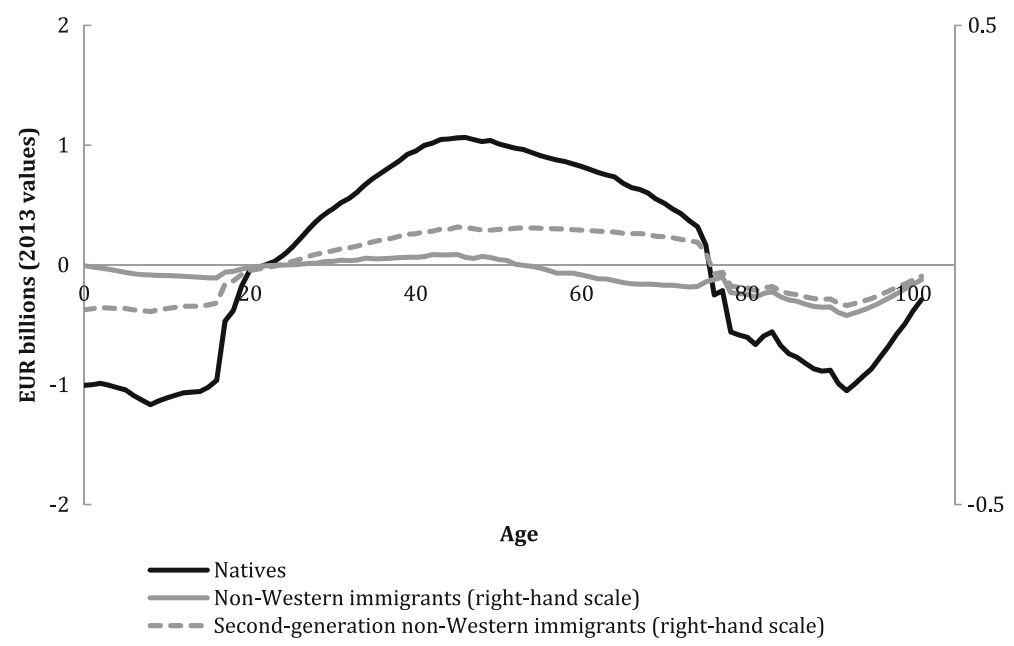

Fig. 4 Total net contributions of the 2013 cohort, by origin. Source: DREAM projection of 2013

The total age-dependent net contribution of natives belonging to the 2013 cohort is indicated by a black line, which corresponds very closely to the total net contributions shown in Fig. 3. This is hardly surprising given that natives constitute the majority of the population, as indicated in Fig. 1.

The non-Western first-generation and second-generation immigrants constitute small population groups; their total net contributions (which are also on a much smaller scale) can be read using the right-hand scale in the figure. It should be noted that it is only between the ages 20 and 50 that first-generation immigrants are projected to make a positive net contribution to public finances, while the contributions from natives and second-generation non-Western immigrants are expected to be positive between the ages of 20 and 75. In particular, this is the outcome of the fact that non-Western immigrants are expected to have significantly lower rates of employment and earnings, resulting in lower tax revenues and higher transfer incomes compared to the other population groups.

\subsection{Calculating the present value of net contributions by origin}

From the total net contributions of the 2013 cohort, the average net contributions per person-year can be calculated for each population group. This measures the extent to which an average individual from the group in question will contribute (positively or negatively) to the public finances in each year during his or her lifetime in Denmark. In practice, this calculation is made by discounting backwards the annual net contributions of the 2013 cohort to the year $2013,{ }^{16}$ and then dividing the amount by the number of person-years.

The number of person-years is calculated as the sum of lifetime years of the members of the 2013 cohort. By the age of 80 , a native who has lived his or her entire life in Denmark is thus counted as contributing 80 person-years, whereas an 80 -year-

\footnotetext{
16 The net contribution in 2013 values is discounted by $1.4 \%$ per year, which is the predicted real rate of interest, corrected for growth, to which the public sector is subject.
} 
old immigrant who arrived in Denmark at the age of 20 only contributes 60 personyears to the total number of person-years of the cohort. The predicted total number of person-years of the entire 2013 cohort is $5,857,711$. Since the present value of the total net contributions of the 2013 cohort is calculated as being EUR -3.7 billion, the average net contribution per person-year is EUR -637 for each cohort member. In other words, a member of the 2013 cohort will on average benefit to the tune of EUR 637 per year from public funds throughout his or her lifetime while residing in Denmark.

As mentioned in the introduction, the annual deficit on Denmark's primary budget balance is 'only' EUR 0.09 billion per year. The reason that the negative contribution of the 2013 cohort is not expected to give rise to great concern is that a sustainable fiscal policy does not require that total revenues should cover all spending for all future generations. This in turn is due to that fact that at the time the members of the 2013 cohort were born, there was an existing population, who had already had many of their expenses paid for - day care, schooling, etc.-and who can therefore be expected to constitute a net surplus for the public purse in the future.

Table 5 shows the net contributions per person-year, distributed by origin. As mentioned previously, the average person in the 2013 cohort will benefit from public spending, with net contributions of EUR -637 per year. The natives generate a net surplus of EUR -695 , which is about $50 \%$ of the amount generated by secondgeneration non-Western immigrants at EUR -1070. Only for immigrants of Western origin the figures are positive, at EUR 2546 and EUR 47 for first-generation and second-generation immigrants, respectively, compared to EUR -2238 and EUR -1070 for first and second non-Western immigrants. ${ }^{17}$ The contribution is higher for firstgeneration than for second-generation Western immigrants partly because many firstgeneration immigrants arrive after school age, and consequently, their day care and their schooling are not paid for by the Danish Exchequer. To a large extent, nonWestern immigrants will also have spent their school years outside Denmark. However, their relationship to the labour market is expected to be much weaker than that of the other population groups, resulting in a large net negative contribution, even though they arrive late on average and do have a relatively high propensity to re-emigrate. The firstgeneration immigrants from Western countries have the highest propensity to reemigrate though, which results in a reduction in expenses related to old age and thus contributes significantly to their sizable net contribution.

The net contribution of natives is also in between the contribution of the two secondgeneration population groups, but these three groups are much more alike as expected, because they are all born in Denmark. They draw on public services about the same, but the second-generation non-Western group does not perform as well as natives on the labour market, they are poorly educated compared to natives, and although the educational gap is diminishing (mainly due to the women), they continue to lag behind. The second-generation Western immigrants perform almost as well as the natives on the labour market; their employment rate is lower but they are better educated and earn

\footnotetext{
${ }^{17}$ These figures illustrate that a net surplus to the public purse from immigration is going to depend crucially on the composition with respect to both country of origin and age at arrival. When, for instance, Storesletten (2003) in a pointing paper on this issue gets a small negative return to the government from immigration, it mainly reflects the composition of immigrant in Sweden at that time, by age but also by country of origin which is not part of his analysis.
} 
Table 5 Average net contributions per person-year of the 2013 cohort, in 2013 values (EUR)

Source: Special run of DREAM
Population

$\begin{array}{lr}\text { Whole cohort } & -637 \\ \text { Natives } & -695 \\ \text { Immigrants from non-Western countries } & -2238 \\ \text { Immigrants from Western countries } & 2546 \\ \text { Second-generation immigrants from non-Western countries } & -1070 \\ \text { Second-generation immigrants from Western countries } & 47\end{array}$

more. It is also an important contributing factor that some second-generation Western immigrants spend years during childhood and adolescence abroad. This is also the case for second-generation non-Western immigrants, but to a lesser extent.

Many young (Western) migrants are in Denmark to study just as Danes are going abroad to study saving the Danish taxpayers money. Viewing this as a kind of an exchange, one could argue that the number of Danes studying abroad should be subtracted from the number of foreign students in Denmark and instead added to the number of natives. However, the Danish students studying in a non-Western country amounts to only $0.5 \%$ of the non-Western (first generation) immigrant population in Denmark, and thus, our result concerning the non-Western population would only be affected very marginally. With respect to Danes studying in a Western country, it is more of an issue. In fact, Danes studying in Western countries amount to $4 \%$ of the Western (first generation) immigrant population living in Denmark. Thus, the result for native and Western immigrants would be somehow affected, making Western immigrants an even better deal for Denmark by making the net deficit of natives even bigger relatively to Western immigrants.

\subsection{The influence of refugees}

When Denmark accepts refugees, it is primarily for humanitarian reasons and a desire to live up to its obligations under the relevant international conventions rather than an attempt to overcome a demographic challenge. When discussing whether future labour shortages can be resolved through immigration, it is therefore relevant to distinguish between refugees and other immigrants.

In general, refugees residing in Denmark exhibit a lower rate of labour force participation than other non-Western immigrants. This is partly due to the traumatic events experienced by some refugees, which result in temporary or permanent health damage. It is, to some extent, also due to the fact that refugees during the last couple of decades have come from the very poorest of the non-Western countries and therefore often have little education and work experience.

In order to calculate the average net contributions among non-refugees, an adjustment has been made whereby the labour market participation rate of refugees is adjusted to the typical historical level for non-Western immigrants who are not refugees. The adjustment is illustrated in Fig. 5, where the age-dependent labour force participation rate is depicted for all non-Western immigrants in 2012. As shown, changing the refugee labour force participation rate leads to a significant rise in the 


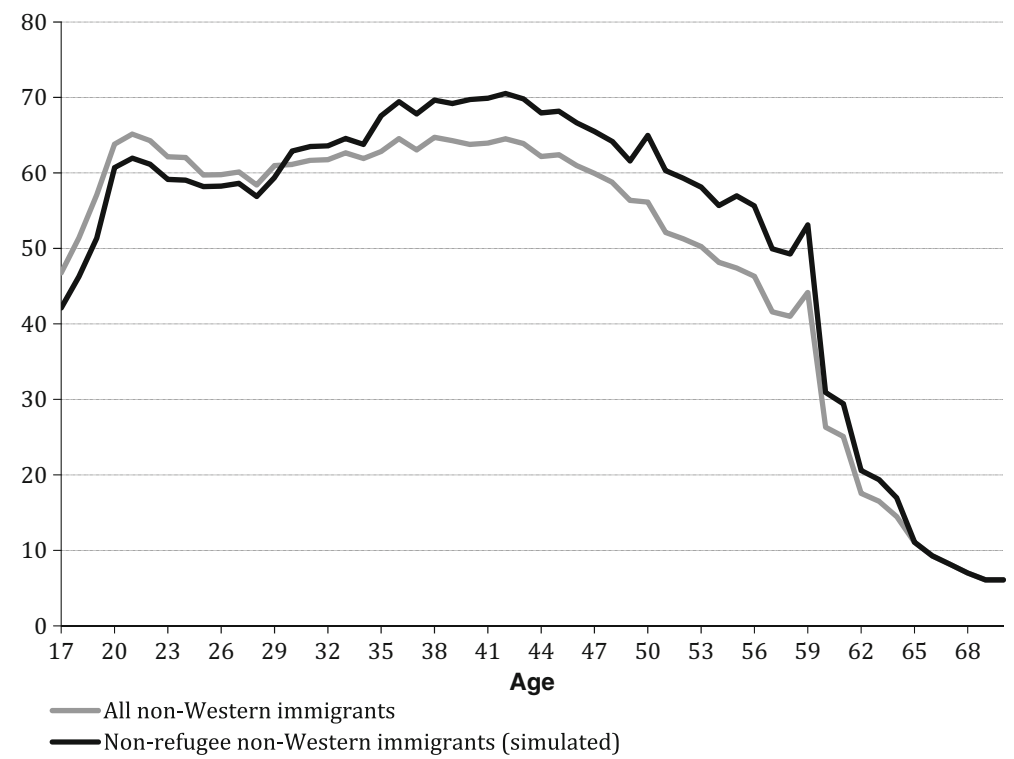

Fig. 5 Age-related labour force participation rate in 2012, percent. Source: DREAM and own calculations

participation rate of non-Western immigrants above the age of 30. For non-Western immigrants under the age of 30 , the adjustment results in a fall in the participation rate, since a large fraction of non-Western immigrants in this age group are students; their participation rate is inferior to that of refugees. The overall change in non-Western labour market participation resulting from the change in refugee participation is implemented in the DREAM model. Consequently, the net contribution of the nonWestern immigrants can be calculated from the adjusted long-term forecast. Overall, the adjustment for refugees results in a rise in the labour force participation rate and, subsequently, an improvement in the average net contribution of non-Western immigrants as shown in Table 6. The table shows that the average net contribution per person-year for non-Western immigrants in the 2013 cohort would rise from EUR -2238 to EUR -1738 if we control for refugees in the manner described above; that is, a $22 \%$ smaller deficit. ${ }^{18}$ The contribution would remain significantly lower than that of natives (EUR -695) and especially than that of Western immigrants (EUR 2546).

The calculation also illustrates that there is considerable potential for improvement through better integration, given that these - admittedly not trivial — changes regarding labour market participation generate a significant improvement in the net contribution if refugees had a participation rate similar to that of other non-Western immigrants. Such improvements are challenged by the fact that the lower participation rate of refugees compared to other non-Western immigrants reflects a variety of differences between the two groups. During the recent couple of decades, refugees have primarily arrived form

\footnotetext{
${ }^{18}$ The reason why the change is not larger when disregarding the refugees is because the difference between the two groups is not that significant. Many refugees obtain jobs and some non-refugee, non-Western immigrant perform pretty poorly on the labour market. Furthermore, only a relatively small fraction of the refugees are newcomers who are the ones with the most immense employment problems. After 10 years (1 year) in Denmark, the employment rate for refugees is $41 \%$ (10\%), and for non-refugee, non-Western immigrants, it is $52 \%(40 \%)$.
} 
Table 6 Average net contributions per person-year of the 2013 cohort, in 2013 values (EUR)

Population

Immigrants from non-Western countries

Immigrants from non-Western countries, adjusting average labour force participation

by simulating improved behaviour of refugees ${ }^{\mathrm{a}}$

Source: Special run of DREAM and own calculations

${ }^{a}$ Calculations made with the labour force participation rate of refugees adjusted so that it corresponds to the level of other non-Western immigrants. The calculations were made using an updated version of the DREAM long-term economic projections of 2011

very poor countries; they are less educated and have many more health issues compared to other non-Western immigrants.

Both the non-Western and the Western groups are very heterogeneous and their subgroups fare very differently on average. Although the best integrated non-Western immigrant group still has an employment rate significantly below the natives' of $79 \%$ in 2014 (e.g. immigrants from Thailand with an employment rate of 62\%), it is more than double the size of the employment rate of the poorest integrated group (e.g. immigrants from Somalia, with an employment rate of 28\%). However, the DREAM macro-model framework cannot handle such heterogeneity, and therefore, we only consider the refugee, non-refugee issue here in addition to the Western, non-Western one.

\section{The marginal fiscal effects of non-Western immigration}

In order to capture the total fiscal impact of immigration, we will, in this section, include two important indirect effects in the computations. The first effect is that immigrants have children. Until this point, we have been focusing on the net contributions of each group separately and, thus, not associated the costs of children to their parents. The second indirect effect is that immigration impacts the overall economy, leading to changes in the relative prices and thus the overall allocation. This section considers the marginal effects of immigration on fiscal sustainability, and here we will take into account the aforementioned indirect effects.

In the previous calculations, it has been assumed that a proportional share of the costs of fixed public goods has been distributed to all population groups. It can be argued that not all public expenditures should be considered as responding to small changes in the size of the population. If the costs of defence, administration and roads do not increase with a marginal increase in the size of the population, or if there are economies of scale, then the additional expenditures resulting from the admission of more members of the population will be below the overall average cost. ${ }^{19}$ In principle, the same could apply to state revenues; but as we have noted earlier, the revenues of the

\footnotetext{
${ }^{19}$ It should be noted that in the immigration literature, expenses related to embassies, immigration officers and the like are traditionally regarded as part of a country's border control and not a cost of immigration, which only counts costs and benefits after a person has been granted a residence permit.
} 
public sector largely stem from taxes paid by individuals, so in fact the income side of the public account is more closely related to the size of the population.

When immigration policy is under discussion, it is in fact the question of changes to expenditure of marginal changes in population size that should be considered. Therefore, in this section, we aim to perform marginal calculations by making small annual changes to the population stock of immigrants — one in thousand - while at the same time keeping the cost of providing the fixed public goods constant.

This is a downwards biased estimate, because the cost of providing a given standard with respect to fixed public goods is never entirely zero. We consider zero to be a good approximation when we consider changes in population size of one in thousands, which is the case when immigration is reduced by say 5000 during a single year $(0.09 \%$ of the population to be exact), but for instance after 30 years with an annual drop in immigration of 5000, the accumulated change has grown to $2.5 \%$ of the population (controlling for mortality and re-migration). Therefore, we also present another estimate of the change in fiscal sustainability assuming that all new immigrants initiate a proportional increase in the costs of providing fixed public goods to the citizens, proportional to the increase in GDP. ${ }^{20}$

\subsection{The exercise: changing the annual immigration}

The deviation from our baseline projection used in the following consists of an assumed reduction of 5000 persons in the annual inflow of non-Western immigrants from 2013 onwards. There is no significance in the choice of this particular figure of 5000 , other than that it is approximately $0.1 \%$ of the population and easy to scale up and down, since the results are scalable to a large extent. The change is shown in Fig. 6, where the projected reductions in size of the population up until 2050 are shown by origin.

Overall, the alternative projection leads to a reduction in the entire Danish population by 152,000 individuals in the year 2050 relative to the baseline projection. The majority of the reduction (around 98,000) is in the size of the non-Western immigrant group (first generation) and, thus, represents a direct effect of the reduction in immigration after taking into account expected re-migration and mortality.

The size of the population of second-generation non-Western immigrants is of course affected as well, since there will be fewer children born when there are fewer women of reproductive age. In 2050, therefore, there would be 37,000 fewer nonWestern second-generation immigrants. Some non-Western immigrants to Denmark marry Danish nationals born in Denmark. According to the Statistics Denmark system of classification, the children of such individuals are considered as being of Danish origin. This means that a reduction in the number of non-Western immigrants also leads to a reduction in the number of natives in the population by approximately 17,000 in 2050 .

When the population is reduced in size, the workforce also becomes smaller-but the amount by which the workforce is reduced and the timing of the reduction depend

\footnotetext{
${ }^{20}$ Technically, the fixed public goods is kept in a constant proportion to GDP. When calculating net contributions, the total cost of fixed public goods is distributed equally among population groups.
} 


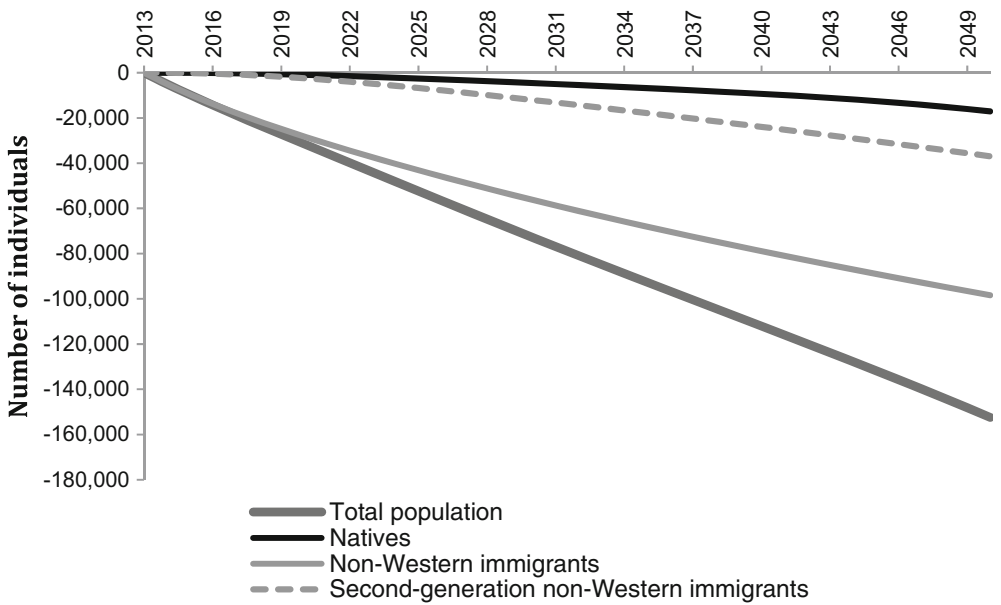

Fig. 6 Reduced immigration: changes in population size relative to the baseline projection. Number of individuals. Source: Special run of DREAM

on the composition of the various population groups and their expected levels of participation in the labour market.

The calculations in this case show an expected reduction in the workforce by 62,000 in 2050 - a reduction which appears relatively modest in comparison with the reduction in the whole population by 152,000 .

There would be almost 50,000 fewer non-Western immigrants in the workforce by 2050 , while the numbers of second-generation non-Western immigrants and natives would be reduced by around 10,000 and 3500, respectively. The reduction in the number of natives and second-generation immigrants in the workforce would begin to take effect from 2035, when the second-generation immigrants are old enough to enter the workforce (Fig. 7).

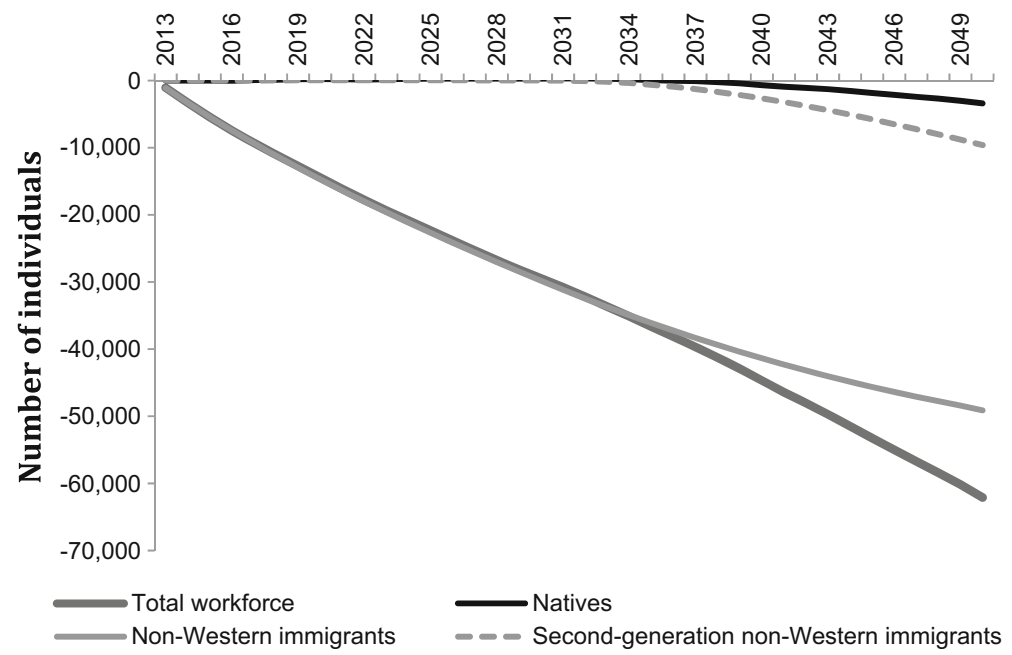

Fig. 7 Change in the size of the workforce relative to the baseline projection for various population groups, in numbers of individuals. Source: Special run of DREAM 
The changes in the size of the workforce are shown until 2050, but the reduction continues in subsequent years and is taken into account when assessing the fiscal consequences of the reduction in the immigration level (see below).

\subsection{The effect on fiscal sustainability of changing the immigration inflow}

When the workforce is reduced, it leads to a reduction in the number of people in employment as well. The aforementioned fall in annual immigration would reduce employment by $2 \%$ and GDP by $1.4 \%$ in the year 2050 relative to the baseline projection. GDP per capita would thus increase from EUR 41,830 to EUR 42,440, or by $1.4 \%$. Nominal wages would increase by $0.5 \%$ and real wages by $0.4 \%$.

As discussed previously, expenditure on fixed public goods is initially assumed to be unaltered, while public expenditure related to individuals would be reduced by $2.1 \%$, producing an overall reduction of $1.6 \%$ in total public spending in 2050 relative to the baseline projection.

The reduced level of economic activity would lead to a reduction in corporate investment and induce companies to raise prices in order to compensate for the lower production level. This in turn would lead to a reduction in exports in 2050 by approximately $1 \%$. However, due to lower production, lower sum of wages and hence lower demand for foreign goods and production inputs by companies and households, imports would also fall. The reduction in imports would be greater than the reduction in exports; hence, net exports would rise by $1.6 \%$ in 2050 .

In total, the calculations show that the public budget would improve (relative to GDP) compared to the baseline projection. This is basically because the rate of labour market participation and the productivity of non-Western immigrants are too low to compensate for the increased public consumption that they generate. The positive effect is furthermore a result of the decrease in the number of second-generation immigrants, which we have learned from the previous sections are also negative net contributors.

Table 7 shows the annual changes in both the primary budget balance and in the sustainability indicator. The starting point is a calculation based on our baseline projection, in which the sustainability indicator is $-0.04 \%$ of GDP and thus practically consistent with fiscal sustainability. This corresponds to a permanent annual deficit in public finances of EUR 0.09 billion.

If the budget balance is distributed according to contributors' origins, as outlined in Section 3, the annual contribution of natives is EUR 0.2 billion, while Western immigrants and Western second-generation immigrants contribute EUR 1 billion and EUR 0.08 billion, respectively. For non-Western immigrants, the net contribution is negative at EUR -1.3 billion, while for second-generation non-Western immigrants, it is EUR -0.05 billion.

The effects of an annual downward adjustment in immigration by 5000 non-Western immigrants are shown in Table 7 . The sustainability indicator becomes positive at $0.08 \%$ of GDP, which corresponds to an annual improvement of the primary balance of EUR 0.2 billion. This means that the sustainability indicator is improved by 0.12 percentage points, and the primary balance by EUR 0.28 billion annually compared to the baseline scenario. A small part of the improvement (EUR 0.04 billion) is attributable to the effects derived from natives and individuals of Western origins and from second-generation non-Western immigrants (EUR 0.01 billion). However, the 
Table 7 Permanent changes in the primary balance in EUR billions in 2013 (2012 values) and in the sustainability indicator (SI), distributed according to origin, as percentages of GDP

\begin{tabular}{|c|c|c|c|c|c|c|c|c|}
\hline & \multicolumn{2}{|l|}{ Non-Western } & \multicolumn{2}{|l|}{ Western } & \multirow[t]{2}{*}{ Natives } & \multicolumn{3}{|c|}{ Total population } \\
\hline & Immigrants & $\begin{array}{l}\text { Second- } \\
\text { generation } \\
\text { immigrants }\end{array}$ & Immigrants & $\begin{array}{l}\text { Second- } \\
\text { generation } \\
\text { immigrants }\end{array}$ & & & & \\
\hline & \multicolumn{2}{|l|}{ EUR billions } & & & & EUR bn & $\mathrm{SI}^{\mathrm{a}}$ & \\
\hline $\begin{array}{l}\text { Baseline } \\
\text { projection }^{\mathrm{b}}\end{array}$ & -1.30 & -0.05 & 0.97 & 0.08 & 0.21 & -0.09 & -0.04 & \\
\hline $\begin{array}{l}5000 \text { fewer non- } \\
\text { Western } \\
\text { immigrants } \\
\text { per year }\end{array}$ & -1.07 & -0.04 & 0.99 & 0.08 & 0.22 & 0.19 & 0.08 & $0.28^{\mathrm{c}}$ \\
\hline Difference & 0.23 & 0.01 & 0.03 & 0.00 & 0.01 & 0.28 & 0.12 & $0.32^{\mathrm{c}}$ \\
\hline \multicolumn{9}{|c|}{ Source: Special run of DREAM } \\
\hline \multicolumn{9}{|c|}{${ }^{a}$ Sustainability indicator (similar to that the S2 used by the European Commission) } \\
\hline
\end{tabular}

largest element of the contribution comes from an improvement by EUR 0.2 billion from the non-Western immigrant group.

As mentioned above, the change in SI of 0.12 is a conservative estimate assuming zero influence on the cost of providing fixed public goods. An alternative is to assume a reduction in government spending on fixed public goods proportionally to the change in GDP. Under this assumption, the fiscal SI would improve by $0.32 \%$ of GDP, if nonWestern immigration is reduced by 5000 annually.

Even the proportional estimate of the improvement in SI, 0.32, is significantly lower than the 0.49 estimated by Schou (2006) for the same immigrant groups. He considers the same estimator and the difference is explained by a strong improvement in labour force participation rates among non-Western immigrants between 2001 and 2008, some of which was due to political reforms and some due to a booming economy.

Finally, we assess the robustness of the results with respect to the immigrants' success on the labour market. Especially, we are curious to know whether the dispersion in unemployment rates between immigrants and natives of 2008 is of significant importance to the result. Between 2008 and 2011, the great recession implied significant increases in unemployment in Denmark, and the unemployment increased relatively more for non-Western immigrants. To investigate this issue, we conduct an alternative computation of the 5000-fewer-immigrants-per-year scenario above in which we increase the unemployment rate of non-Western immigrants (by two percentage points) keeping the one of natives (and Western immigrants) fixed so as to mimic the actual unemployment difference between the two groups between 2011 and 2013, the bottom of the great recession in Denmark, which was around 7.7 percentage points compared to 5.8 percentage points in 2008 . 
The results did not change much. Instead of improving sustainability by $0.12 \%$ of GDP according to our conservative estimate, an annual reduction in non-Western immigration improves the SI by $0.13 \%$ of GDP. The proportional estimate of our experiment is practically unchanged, because the difference between the two estimates is defined by the cost of fixed public goods that does not depend directly on labour market status. ${ }^{21}$ Looking at the average net contribution per person per year of the 2013 cohort, that did not change much either. In the conservative scenario with constant spending on fixed public goods, it decreased from -2238 EUR to -2364 EUR for the non-Western immigrant group for whom the unemployment assumption was changed.

Thus, given the structure of the Danish economy and the pattern of immigration, the fiscal sustainability is affected by a magnitude between 0.12 percentage points and 0.32 percentage points of GDP when the annual inflow of non-Western immigrants changes by 5000 individuals, a change representing approximately $0.1 \%$ of the total population annually.

\section{Summary and conclusions}

In this paper, we have studied the fiscal implications of immigration to Denmark. A general result throughout the paper is that the fiscal impact of immigration depends crucially on the sending country. The expected fiscal impact of the entire non-Western population group residing in Denmark will amount to a deficit of around $1 \%$ of GDP in 2014, and in the year 2050, residents of non-Western origin will still be making a negative net contribution adding to the challenges of the Danish welfare statechallenges which will exist in part as a consequence of the ageing population. The population of Western origin will oppositely be generating a net surplus both in 2014 and in 2050. The reasons for the expected deficits lie in the weak labour market performance of non-Western immigrants as a group and the fact that people with a low level of education, which includes many non-Western immigrants, tend to retire early; both these factors operate in combination with the universal Danish welfare system.

Apart from this first cross-section computation, we have performed two other types of computations both forward looking. Our second computation looks at the average net contribution per person to the public purse for each year that an individual is in Denmark, and we present an average for each of the five population groups considered. This analysis shows that second-generation non-Western immigrants have come a long way in comparison with their parents in terms of their financial relationship with the welfare state. Although the second-generation non-Western immigrants make a negative contribution of almost twice the level of natives (who also make a negative net contribution), the first-generation makes a net cost of three times the level of natives. Disregarding the refugee group decreases the net cost of non-Western immigrants by around $20 \%$.

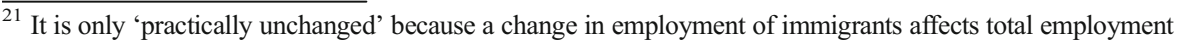
and thus relative prices.
} 
By way of comparison, first-generation Western immigrants on average make a significant positive net contribution to public funds, while second-generation Western immigrants more or less break even. The difference to the natives is mainly explained by the fact that the second-generation Western immigrants are better educated than natives and that many spend some years outside the country during childhood and adolescence. By focusing on net average contributions of each origin and generation group in isolation, these computations neither allow us to identify the impact of immigration on the overall economy nor the relationship between immigrants and their children, something that affects the public purse in a nontrivial way. Thus, our third computation aims at quantifying these indirect effects by performing a marginal shock to the population using a dynamic computable general equilibrium model with overlapping generations. Here we calculate how fiscal sustainability responds to changes in the population induced by a reduction in annual immigration flows. We show that the last 5000 people in the annual immigration forecast will create an additional deficit for the public finances of, on average, EUR 0.3 billion per year, which is equivalent to a decrease in the fiscal sustainability indicator of 0.12 percentage points. This result is robust to the way the nativeimmigrant unemployment gap changes with the business cycle. Assuming a gap of the magnitude found at the height of the recession years 2011-2013 only increases the indicator from 0.12 to 0.13 .

These figures should be interpreted as the public cost of a marginal change in immigration in that they do not take into account the costs of providing fixed public goods, or as a conservative or lower bound estimate of the effect on net costs in case the change in population size is not marginal. For completeness, we have also computed an alternative estimate by assuming that the provision of fixed public goods changes proportionally with the size of the economy, GDP. Doing so, the SI becomes 0.28, implying that the 5000 fewer non-Western immigrants give rise to an improvement in the SI of 0.32 percentage points. Thus, a change in non-Western immigration to Denmark of a magnitude of annually around $0.1 \%$ of the total population will change the fiscal sustainability indicator between 0.12 and 0.32 percentage points depending on what is assumed about its effect on the provision of fixed public goods.

In conclusion, let us return to our initial question. Is it possible for a country like Denmark to use immigration to strengthen its fiscal sustainability? The answer is yes-provided that the immigrants have good prospects for employment and that they remain active on the labour market for a long time. As it is now, immigrants from Western countries seem to have a positive impact on the economy, while non-Western immigrants have a negative fiscal impact, even if we control for the low participation rates of refugees. The negative effect of immigration from non-Western countries is the result of low rates of employment and of early retirement from the labour market. Denmark is different from other countries both because of its welfare model and because of its history of attracting many immigrants with weak labour market prospects. The results reported here are forecasts based on the boom year 2008 where the native-immigrant unemployment gap was small. But the results are robust with respect to a change in the gap similar to what could be observed during the recession years following 2008 . 
Acknowledgements The authors thank three anonymous referees for their helpful comments and suggestions.

\section{Compliance with ethical standards}

Funding This study was funded by The Rockwool Foundation, Kronprinsessegade 54, 1306 Copenhagen K, Denmark (grant 1136).

Conflict of interest The authors declare that they have no conflict of interest.

\section{Appendix. Dividing up the budget by sub-populations}

In this paper, the total public sector budget is broken down according to the gender, age and origin of individuals. Dividing up public income and expenditure demands the use of a set of distribution keys. The key to be used depends on which type of income or expenditure is involved and on the extent to which the item in the budget can be linked to a specific population group.

Some budget items are distributed directly by definition, while others have to be distributed subsequently. Overall, the following six principles describe the way budget items are distributed by population groups.

Group 1 consists of items which are distributed directly by DREAM according to gender, age and population group. This group is composed of the many items which are linked to individuals by the definitions in microdata, such as wages, labour market contribution tax, student grants, old-age pensions and disability pensions.

Group 2 is made up of items which are attributed only according to gender and age in DREAM. These items are subsequently distributed according to country of origin by relating them to the gender and age distributions of the origin groups. They include, for example, inheritance tax.

Group 3 consists of items which are attributed only according to age in DREAM. In order to divide up these items according to gender and origin, one or other of the following is used as a distribution key:

(a) Disposable income (excluding interest). Examples of items attributed in this way are VAT and other indirect taxes.

(b) The proportion of the adult population (above the age of 16) made up by the population group. These items include, for example, voluntary contributions to benefit schemes and capital transfers from the public sector.

Group 4 consists of items which are not initially distributed. These are distributed according to gender, age and origin through the use of one or other of the following distribution keys:

(a) Share of the adult population (above the age of 16) made up by the population group in question. This distribution key is used for items which are only given to or required from the adult population, such as corporate tax. 
(b) Share of the entire population made up by the population group in question. This distribution key is used for items that concern the entire population. In particular, it includes collective public services, such as central administration, defence and road construction.

Open Access This article is distributed under the terms of the Creative Commons Attribution 4.0 International License (http://creativecommons.org/licenses/by/4.0/), which permits unrestricted use, distribution, and reproduction in any medium, provided you give appropriate credit to the original author(s) and the source, provide a link to the Creative Commons license, and indicate if changes were made.

\section{References}

Bauer T, Larsen C, Matthiessen PC (2004) Immigration policy and Danish and German immigration. In Tranæs T, Zimmermann KF (eds) Migrants, work and the welfare state. University Press of Southern Denmark, Odense, p 31-65

Borjas GJ (1990) Friends or strangers: the impact of immigrants on the US economy. Basic Books, New York Danmarks Statistik (2013) Indvandrere i Danmark 2013. Statistics Denmark, Copenhagen

DREAM (2013a) Danmarks fremtidige befolkning - befolkningsfremskrivningen 2013. Copenhagen

DREAM (2013b) Langsigtet økonomisk fremskrivning 2013. Copenhagen

Dustmann C, Frattini T (2013) The fiscal effects of immigration to the UK. The Econ J 124(580):F593-F64

Flood L, Ruist J (2015) Migration, en åldrande befolkning ord offentliga Finanser. Bilaga 6 till Långtidsutredningen 2015, Statens offentliga utredninger SOU., p 95

Gerdes C, Schultz-Nielsen ML, Wadensjö E (2011) The significance of immigration for public finances in Denmark. Rockwool Foundation Research Unit study paper no. 35. University Press of Southern Denmark, Odense

Hinte H, Zimmermann KF (2014) Does the calculation hold? The fiscal balance of migration to Denmark and Germany. IZA Policy Paper no. 87

Peri G (2014) Do immigrant workers depress the wages of native workers? IZA World of Labor 2014:42

Ruist J (2014) Free immigration and welfare access: the Swedish experience. Fisc Stud 35:19-39

Ruist J (2015) The fiscal cost of refugee immigration: the example of Sweden. Population and Development Review 41(4):567-581

Schou P (2006) Immigration, integration and fiscal sustainability. J Popul Econ 19(4):671-689

Storesletten K (2003) Fiscal implication of immigration - a net present value calculation. Scand J Econ 105(3):487-506

Tranæs T (2012) Immigration laws affect integration - the politicians decide how., International Organization for Migration

Tranæs T, Zimmermann KF (2004) Migrants, work and the welfare state. University Press of Southern Denmark, Odense

Wadensjö E (2000) Immigration, the labour market, and public finances in Denmark. Swed Econ Policy Rev 7:59-84

Wadensjö E (2007) Immigration and the net transfers within the public sector in Denmark. Eur J Polit Econ 23(2):472-85

Wadensjö E, Gerdes C (2004) Immigrants and the public sector in Denmark and Germany. In: Tranæs T, Zimmermann KF (eds) Migrants, work and the welfare state. University Press of Southern Denmark, Odense 